\title{
Demographic change: Ecological and polycentric challenges for white Christianity in urban South Africa
}

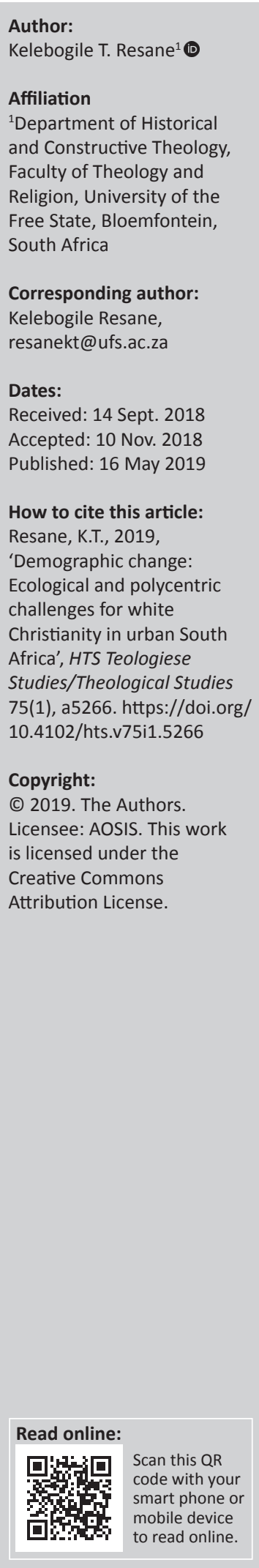

This article demonstrates how white Christianity in urban South Africa is fated by demographic change. The repeal of apartheid in 1994 enacted some sociocultural changes in urban South Africa. The white population exited the city and town centres, followed by the black South Africans. The historical relationship of the government under the National Party (NP) and the Dutch Reformed Church (DRC) led to latters' redundancy in the cities. The cultural development towards multiculturalism led to polycentric focus where the suburban peripheries and the city centres experience some form of socio- and cultural-economic developments. Two proposals are made to redress the situation. Firstly, a rethinking was suggested of the theology of the city, which should always demonstrate solidarity with the poor and the marginalised trapped within the decadent city culture. Secondly, a missiological refocus was suggested, which should pursue, embrace and include activities that are not paternalistic.

Keywords: Church; City; Culture; Challenge; Theology; Missional.

\section{Introduction}

South Africa's religious affiliation and convictions are complicated by a difficult historical relationship between the church and the state. The Dutch Reformed Church (DRC or NGK) and the National Party (NP) were bedfellows in legitimising apartheid (Resane 2017:125-126). The apartheid state historically abused the church to promote oppression of the majority of the populace through misinformation, ignorance or silence. It kept the white Christian community ignorant, as a norm (Botman in Lugo 2000:349), by denying them information so that they would align themselves with the status quo. The DRC, on the other hand, endorsed and provided the apartheid state with moral and theological justification to perpetrate social injustices. Generally, the white Afrikaans Christianity played a role in perpetrating apartheid ideology. Masuku (2014) correctly points this out:

The churches were divided among those who embraced apartheid, those who rejected it and those who assumed a neutral position or 'quiet diplomacy'. (p. 2)

The aim of this article is to demonstrate how white Christianity in urban South Africa is fated by demographic change. One should remember how the city centres had become the autochthonous centres for white people who subscribed to the Christian faith - the space where their supremacist ideals found expression. During the early 1990s, the then white exclusive cities, including their suburban locales, welcomed the people who were previously excluded (Renkin 2017:6).

The repeal of apartheid in 1994 brought forth some sociocultural changes in urban South Africa. The city population settlement started taking a new composition. For instance, the rise and increase of informal settlements, especially on the verge of the cities, towns and townships, became a population settlement phenomenon:

Since 1994 the urban landscape of the city has changed considerably in some ways, but - in essence - it could indeed be asked if the apartheid city has been fully dismantled. (Ribbens \& De Beer 2017:3)

Many South Africans, especially white people, exited the city centres and suburbs closer to the cities to occupy the economically elite suburbs afar. The city centres opened up to the foreign nationals who crossed borders into South Africa either as economic or political refugees. This left South Africa as one of the largest recipients of refugees and asylum seekers on the continent (Kritzinger \& Mande 2016:4). South African rural men left their wives, children and parents on the native or tribal lands. When men moved into the cities on their own, prostitution moved in with them. This led to family and community breakdown on a large scale, not to mention disintegration of African communal and cultural values (Bakke \& Hart 1987:36). This reinforces Parsley's (2007) thesis that when worldviews collide, nations hang in a balance, with the battle for cultural survival 
surging on. The South African population shift, like many socalled Third World cities, metamorphosed into a new landscape resettled by the poor, the foreign nationals, the hawkers, the drug dealers and the addicts.

\section{The state of South African urban centres}

This article focuses much on the urban centre as a city or town centre, including the suburbs on the verges of these centres. The two poles that coexist irreversibly are the success of cities or their failures:

The existence of cities and expressions of religion are here to stay. Religion and the urban context have interacted either positively and/or negatively since the inception of both realities. Religion was in some cases the reason for the origin of cities. (Geel \& Beyers 2018:2)

South African cities evolved into ghettoes, or decayed cities. The architecture is dilapidating, morals denigrated and environment polluted:

Cities are believed to be especially sinful, and the inhabitants unusually hardened against the gospel. Even if it were not so, how could Christians expose their children to the corruption of the city? Ministry there is for celibates only - or is it? (Bakke \& Hart 1987:7)

Security and safety has become an excuse wrapped up in a lie (Toler \& Nelson 1999:25), while in the real sense it is escaping from swart gevaar and emergence of xenogenesis reality. Renkin (2017) asserts that:

Migration and the presence of migrants tend to be presented as problematic and negative by the popular media, academia and in political debates. (p. 1)

Cities continue to reflect the persistence of the apartheid socio-economic geography (Ramphele 2017:15), which is the space where inequality due to cultural dislocation is observable and detectable. When people lose their cultural values, or become psychologically trapped in cultural decay, they become vulnerable to humiliation and susceptible to all forms of abuse. The consequences include dysfunctionality of the family and other sociocultural relationships. 'People who are humiliated and treated with disrespect are unlikely to become good spouses, partners or parents' (Ramphele 2017:16).

\section{Ecological and polycentric challenges}

The new South Africa of Nelson Mandela became a beacon of hope to run to for shelter and a better life for survivors of war from West and East Africa and the economically destitute Southern Africa. The arrival of these foreign nationals affected the human ecological imbalance that was for centuries built on racial segregation. The cultural development started to take a different polycentric focus where the suburban peripheries and the city centres entered into some form of socio- and cultural-economic developments. This population dynamic comes like tectonic shifts and systemic malfunction. It is an inevitable phenomenon pointed out by Van der Westhuizen (2016):

In the wake of the collapse of apartheid certainties, new locales arise in a proliferation of identities. The shift is away from singular entities of power to decentralised social and economic organisation. (p. 3)

The flight of the white people from the city centres is often justified by preconceived ideas that people of mixed race are more prone to crime. This means, if many black people move into the neighbourhood, crime will escalate, property values will depreciate and, of course, the neighbourhood will deteriorate (Diangelo 2018:62). The cultural convergence threatens the white identity and self-determination. Black people are always regarded as subhumans, and in some cases, as species of the lower class. Wekker (2016) says class status is acknowledged:

For many white people, there is an automatic equivalence between being black and being lower class; these two axes of signification are closely related, quasi-identical. Retaining the connection between whiteness and class superiority, that is, securing white superiority requires automatically assigning blacks to lower-class status. (p. 47)

The flight of the white people from the city centres affected the church. White church buildings and religion became redundant. Verster (2013) points out some examples of redundant churches and the numbers increase rapidly:

The NGK Tweetoring church in Bloemfontein no longer has a permanent congregation and now provides the base for 'Towers of Hope', a multidenominational outreach action in the CBD. The former NGK Monument has been reconstructed into a Hyundai motor dealership, and other churches, such as the GK Bloemfontein-Wes, were demolished. In cities such as Welkom, churches have lost congregations and the re- and disuse of buildings is evident. The trend is occurring not only in the Free State, but also throughout South Africa. A building in Highlands North, Johannesburg (corner of Athol Street \& Joseph Road) is now, as a Video Town outlet, almost unrecognisable as a former church. (p. 61)

Verster's (2013) research demonstrates the polycentric impact of the flight of the white people from city centres and how this has affected the church and brought into question the South African church's missiological outlook. Her research focuses on the Free State, especially Bloemfontein, but the scenario reflects a national, and even an international phenomenon.

Many NGK buildings are used by different faiths in Johannesburg. For instance, the DRC Langlaagte functioned as the Abraham Kriel orphanage and later as the home for an independent Pentecostal church, known as Glory Divine World Ministries. It was sold in 2012 to the Muslim community for use as a Mosque (De Villiers 2012: online, Walker 2011: online).

The original Methodist church located on 24 Chatou Road, Johannesburg, was converted in 1986 to become the offices of architects Britz and Scholes for which the practice received 
the 1987 IS AA (now SAIA) Merit Award. ${ }^{1}$ In 2009, the church became known as the Pink Church, a venue used for exhibitions, music evenings and various other functions. ${ }^{2}$

In the Western Cape, the Kalk Bay Theatre and restaurant is situated in what used to be the NGK Kalk Bay.

NG Kerk Bloemfontein-Oos (1937-1995) struggled during the early 1990s owing to changing demographics of the eastern smallholdings and the expansion of the informal settlements towards the south-east of the Bloemfontein CBD. The building is now used by the Apostolic Faith Mission (AGS).

The NGK congregation of Bloemfontein-Wes stood on the corner of Charles Street and Second Avenue. The site was sold to the Georgiou Trust and the church was demolished in 2001 to be replaced by the regional headquarters of Nedbank (Coertzen 2001: online). The main reason behind the decision to sell the building was the high maintenance cost of the old building and the relocation of members of the congregation towards the suburb of Langenhoven Park.

The congregation on the south eastern perimeter of Bloemfontein (NGK Rodenbeck) was also affected by the demographic change. The development of the informal settlements in the 1990s resulted in the church centred in the Bloemside township/informal settlement. The government at the time had made the decision to allocate the area around the church for low-cost housing/informal settlement, and after negotiations, the provincial administration paid out the amount of R1.8 million. The building was donated to the Free State Province Council of Churches (FSPCC), the regional level of the SACC (Göranzon 2011: xxi).

The Gereformeerde Kerk (GK) Bloemfontein-Oos congregation merged with the GK Bloemfontein founding congregation in 2007 after services were no longer viable owing to the decline in membership and the change in demographics of its catchment area (Harris et al. 2010:25). The congregation decided to sell the building to Roadmap Ministries with the understanding that it will continue to function as a place of worship.

NGK Brandwag borders a business park to the south and residential area to the north and west. The demographics of residents have also changed and many houses now function as student accommodation. The changes in demographics and the introduction of commercial activity presented the congregation with declining membership and financial difficulty. The congregation merged with Bloemheuwel in 1999. The Kairos Baptist Church then used the building for a number of years. In 2012, it changed hands again and is now rented by the Shofar Church of Bloemfontein. The building also serves as a meeting hall for various associations.

1.http://www.artefacts.co.za/main/Buildings/meritawardframes.php

2.http://www.jhblive.com/live/venue_view.jsp?venue_id=43481
This is indicative of the reality that racism as an ideology contributes significantly to the flight of the white people from the city centres. Racism in South Africa is now not legislative but subliminal and conscious-buried in people's perceptions. Indeed, 'Racism is a systemic, societal, institutional, omnipresent, and epistemologically embedded phenomenon that pervades every vestige of our reality' (Akintunde 1999:1). Instead of changing their worship style to accommodate the demographics of the area, the white people opt to exit the community or sell the church building for another purpose. This challenges the theological and ecclesial stance on population movements. Ilo (2017) correctly alludes to this reality:

This requires reading the signs of the times and paying attention to the inner enrichment of particular and universal contexts of faith. It also calls on theologians to become radically open to the surprises of the Holy Spirit and adopt theological humility before the mysteries of God, especially in the actual faith and everyday experiences of God's people in Africa. (p. 37)

Around the country, especially in the big cities, local congregations are closing their doors. Regel and Schulz (1995:11) found out that most of the reasons for this pessimistic prognosis are to be found within society, and the tragic fact is that so many churches are failing to discern the signs of the times and neglecting to seek the spiritual discernment and vitality to meet the challenges. Maintenance mould gives churches some comfort zones. The tendency to stay the same leads to annihilation. The church growth strategists, Stetzer and Rainer (2010:18), say that: 'Churches do not change until the pain of staying the same is greater than the pain of change'.

This article addresses the ecological challenges, where landscape and human action are integrated, and the polycentric challenges that integrate neighbourhoods and maximise proximity. As mentioned above, city centres usually accompany some form of 'urban decays' where infrastructure includes dilapidating architecture, disruptions or breakages of electric and plumbing reticulation, and uncontrolled hawking on the pavements. Davis (2007:121150) highlights vulnerabilities within the toxic ecology of the present-day urban planet such as hazardous geology, surplus of industrial and human waste, anarchic traffic, looming infernos, little to no portable water and living incubators for diseases. In summary, Davis captures this polycentric challenge in four Ds: Death, Disaster, Decay and Deception. All these, including humans, affect ecological balance and the polycentric shape of the city. It is true that:

The city has undergone major transformations over the past few years. Even the condition of the environment is no longer favourable. These issues have caused the subjects (urban dwellers) to become part of the process of de-subjectification. (Geel \& Beyers 2018:4)

City situation needs some redress. The urban environment has its own, unique challenges that stifle growth and prosperity for all citizens in the city (Baron 2017:1). The 'whiteless' and 'South Africanless' cities still remain redeemable. Urban poverty ushers in the opportunities for 
ecclesiological and missiological expressions - the incarnation of the love of Christ. Departure from the CBD (Central Business District), citing foreign or racial encroachment, is prosaic. It is a wrong judgement based on inhibitive and reductive rationale. There is always an accompanying bigotry that prescribes and describes people negatively. However, as Zille (2016) of the opposition Democratic Alliance cautions:

People are not defined by creed, dogma, or ethnic origin, but by kindred spirits who cross their life path and, through shared values, form a bond of love that extends beyond death. (p. 466)

South African democracy is failing to integrate the city and the original inhabitants. The so-called encroachers from the rural areas and across the borders suffer discrimination, prejudice and social marginalisation. Ramphele (2017:15) captures the truth that: 'Human rights and human dignity are not adequately reflected in our social relationships'. Indeed, the cities had become centres of abuse instead of growth and empowerment. Ramphele (2017:15) continues the argument that: 'The fraying of our democracy is exacerbated when we ignore our cities as sites of transformation'.

\section{Multiculturalism: An inevitable phenomenon}

Kiaziku (2009:115) alludes to the fact that 'societies today are almost all multicultural as well as multi-religious'. Soal and Henry (2018:2) reinforce the concept that: 'Culture is also dynamic. Diversity between cultures is the norm and, unfortunately, the main issue triggering conflict'. Cities and towns are the melting pot of multicultural dynamics. Obnoxiously, intercultural and multiracial society threatens many South Africans, regardless of race; hence, the incidence of sporadic homophobic attacks and racial slurs in public spaces such as beaches, restaurants, workplaces and so on. The perilurban centres, such as Hillbrow in Johannesburg and Sunnyside in Pretoria, are predominantly resided by the foreign nationals. Generally, South Africans of all races, especially white people, unreservedly tell their unsafe feelings in these centres. This is because of the historical fact pointed out by Prozesky (2016:166) that apartheid as an unloving social system was created and maintained by a largely Christian population. This is engrained and embedded into their minds that exit and exodus from the multiracial threat becomes inevitable. As Rhodes (1998:15) asserts: 'It is hostility, not hospitality, that most aptly characterizes the current climate of our culture'. Inevitably, like the ancient urban eastern Mediterranean region, the emergence of strong integration capacity, the transnational, transcultural character and multi-social strata nature of South African city churches is real (Tilly 2016:227). Unfortunately, this needs no interpretation than failure to 'embrace the poor and foreign nationals around the notion of God's radical choice to embrace and celebrate every human being in a community' (Hankela 2013:75). The urban centres around the world had become spaces of conflict. Sheldrake (2010) engrosses this fact that:

We cannot ignore the fact that while cathedrals symbolized a Christian vision of human-divine unity they also solidified the divisions of the social order. (p. 189)
It is worthy of note that the church, from the day of her New Testament inception, was in a multiracial setting, consequently a multicultural component in her entity. Soal and Henry (2018) remind us that:

In Acts 2, we see many cultures gathered for Pentecost and supernaturally united by the Holy Spirit into one church of diverse cultures. Again, today globalisation is placing many cultures in one geographic area. The Trinitarian nature of God enables all humans, made in his image, to again be one in Christ. (p. 9)

Despite the flight of the white people from the city centres, some ministers in the DRC who aspire inclusivity in their churches have a flickering of hope. The 10 DRC ministers interviewed by Rossouw (2016:386) pointed out their challenge to integrate their identities into the larger diverse narratives in the South African society. The resistance and reservation for multicultural inclusivity from the DRC seems to be losing ground, regardless of lack of solidarity with the changing demographics to accommodate all people instead of fighting for self-asserting identity.

\section{The intervention}

\section{Rethinking theology of the city}

The theology of the city is a theology that always demonstrates solidarity with the poor and the marginalised trapped within the decadent city culture. Theology should speak and address the issue of demographic changes, not to change or delay them, but to see how churches should refocus on integration and their prophetic role. This is the real incarnation of the character and compassion of Christ. The church cannot retreat:

Research shows that increased immigration strongly correlates with increases in anti-immigrant sentiment. This suggests the need for communities to strive not simply to become diverse and multicultural, but also to use strategies - such as facilitated, faceto-face dialogue as depicted in this article - aimed to foster mutual respect across deep divides. (Johnson 2018:2)

All humanity are foreigners in whichever life spaces they exist. This is a crucial nexus and challenge for integration in contexts of migration. The theology of the city should challenge the country's citizens to consider migrants positively, and migrants to avoid self-exclusion:

This theological and practical theological approach provides opportunities for constructive engagement on churches that reject the diversity of the ideal, integrated church that contributes to overcoming the challenges posed by migration. (Magezi 2017:230)

Migration and demographics dynamics are theological. Theology and human existence should meet meaningfully. This is justified by the fact that: 'Theology is a dialogical movement, both internal and external to the subject' (Ilo 2017:51). Perspectives and frameworks should engage with the inner damage of prejudice, the errors of judgement about others, listening or welcoming others, shutting ourselves behind doors or even avoiding the double standard of preaching for human rights while at the same time excluding 
those who are not like us (Selçuk 2018:240). The rallying call is engaging in order to build bridges. Kerygma is not a distant activity but an involved one. The church should lead into the world to get an exposure whereby people can begin to recognise the vital importance of building bridges. 'They not only know it, but they also feel it'. (Lewis \& Wilkins 2001:78). Life in action is fully understood. To understand completely one has to be there - engaged and involved (Rainer \& Geiger 2006:31). The ecclesial community calls to internalise the reality that contexts will keep changing:

Christian theology in Africa is contextual. But the African context is diverse and always changing. The traditional African culture is not the same as our modern African context. (Palmer 1994:8)

The authenticity of theology rests in its application and appropriation in missionary expression. Missiology is not just the study on missions but the practical application of theology. Missions are theology in action. Chester and Timmis (2008) are correct that:

Authentic theology must be shaped by what we might call a missionary hermeneutic. Theology divorced from this context is essentially barren, self-referential, and indulgent. (p. 156)

Individualism has invaded African communality (ubuntu/ botho, ujamaa, etc.). This contributes negatively towards ecclesial cohesion and liturgical expression in solidarity with the body of Christ. The remaining motif stands testimony to the fact that the Christian faith boldly and counterculturally invites us to think of others as more important than ourselves (Frazee 2001:43). Perceptions must change to realise that 'cathedrals are places of social connection and of community definition' (Sheldrake 2010:192).

\section{Refocussing missiological interpretation}

The church and her leaders should engage other sciences in order to capture a clear picture of demographic change and to develop some strategies to address the issue. Indeed, Sundberg (2000) is correct that:

Churches must resymbolize their historic faiths in light of prevailing cultural imperatives taken from the natural and social sciences. (p. 24)

Missional engagement is delayed by internal conflicts. The Afrikaans Dutch Reformed family churches are for the past two decades embroiled in internal squabbles regarding confession, racism, polity and so on. It was obvious that there was no attempt to remedy the errors of the past. As such, an already chaotic country plunged into further riots, and the DRC started to embark on a road less travelled. Strauss (2018a) confirms this self-searching inevitability:

The DRC reacted to this situation with the following documents: Kerk en Samelewing [Church and Society] 1986 (KS 1986) and Kerk en Samelewing [Church and Society] 1990 (KS 1990), in which it rejects a qualified apartheid - for the DRC the bad or negative side of apartheid (KS 1986:52, 1990:40; Strauss 2018b:9). Some issues were more sharply and more clearly defined in the ensuing KS 1990 - more about this later. (p. 1)
The result is that the missional focus is significantly affected by these ecclesial erratics. Gibbs and Coffey (2001) are correct that:

Churches can become so traumatized by their internal problems that they fail to notice that society at large is in the midst of a cultural shift of seismic proportions, which affects every area of society. (p. 24)

White Christianity in South Africa, in pursuit of racial and political identity, abandoned the missional responsibility and religious duty of solidarity with other races through disengagement by exodus from the city and town centres. Carter (1993:7) of Yale Law School had foreseen that: 'The effort to banish religion for politics' sake has led us astray'. Culture and language are used as a scapegoat for multiracialism in obeying Christ for formation of the new community. Rhodes (1998) challenges this notion:

If we were to form a ministry directed toward new immigrants from Africa, we would have to form a multicultural, multitribal, English-speaking African ministry. (p. 51)

There is a need for what Kgatla (2016:69) calls the missiology of radical discipleship. This involves expanding one's space of life unconditionally to embrace the other (the poor) in such a way that the 'haves' could see it as hating oneself. It is a missiology grounded in the theory of radical interactionality, interconnectedness, interdependence, relationality and Ubuntu, and it is thus a theology of reciprocity and mutuality (Kgatla 2016:70). The radical missiology promotes a dialogue that views people as the highest form of wealth and crest of God's creation (Aristide 1993:178).

The South African white perception of black people as the mission field is regrettable. This supremacist and paternalistic ideal hampers the multicultural missional endeavours. This is a departure from the essence of ecclesia - where citizens, regardless of their ethnic affiliation, were called to decide matters affecting the common welfare (Banks 1988:34; Clapp 1996:80). McClung (2008) points to the fact that:

The ecclesia was the power center of culture and life. It was the ecclesia that directed the affairs of the city. They were at the center of things, not the prisoners of a walled-off asylum. (p. 9)

The supremacist ideals are dangerous; the ideal is to dialogue in order to pursue the ideal, as Toler and Nelson (1999:31) assert: 'The best churches are not perfect, but they are forever pursuing the ideal'. One of the biggest cries for missional engagement is by De Beer (2017), and this cry is genuine and challenging:

If the church fails to respond in appropriate and bold ways to the challenges South African cities and particularly the urban poor face, and if theological education deliberately chooses to locate itself in disembodied ways as immaterial, intellectual or 'scientific' exercise, largely detached from the struggles of the urban masses who are poor and condemned to urban fringes and who happens to form the majority of the church's urban membership, then God has no obligation to continuously try to change the course of history, or to liberate the urban poor, through the church. (p. 1) 
The South African white missiological approaches should change and pursue embrace and inclusion (Volf 1996:75). Missional activities are not supposed to be paternalistic where 'others' and/or 'them' become a missional target. This missiological construct is a historical and cultural evolutionary genesis. It is highlighted by Verster (2013) that:

The Free State NGK declared that it was the duty of every Church council to do missionary work within the boundaries of their parish regarding the black population. Instruction and services were given, albeit in separate buildings. Black catechists were appointed as assistants, but black or coloured worshippers did not attend services in the 'white' churches. But exceptions were made in cases such as funerals, especially in rural areas with smaller communities. (p. 22)

It is high time to restore the beauty of the multicultural cities than abandoning them. Rogers (1997) appeals for principles that are spiritual as much as functional. He argues that a city needs:

... to be just (accessible to all and participative), beautiful (an aesthetic that uplifts the spirit), creative (stimulating the full potential of all citizens and able to respond easily to change), ecological (where landscape and human action are integrated), of easy contact (where communication is facilitated and public spaces are communitarian), polycentric (integrating neighbourhoods and maximising proximity), and finally diverse, expressing the pluralism and multiculturalism of the contemporary city. (pp. 167-168)

The white church in South Africa needs a thorough orientation towards change of mind regarding the cities. Renkin (2017) makes an appeal:

Deliberate conscientisation is needed for congregants to contribute to dispel the myth that migration causes poverty, unemployment and the decay of public safety and to integrate migrants into society. Churches play an important role to partake in the creation of a healthy and vibrant society that is seeking God's shalom for the city. (p. 8)

The project zone should be missional practices for inclusivity that, according to Rossouw (2016:390), includes liturgical listening, linguistic pilgrimage and sacred meals with strangers. This opens a platform for dialogue, as it is well-known that: 'A common thread of dialogue and listening runs through the development of missional theology' (Rossouw 2016:390).

\section{Conclusion}

Demographic changes are inevitable. It is a universal phenomenon. The church is to embark on eschatological deliberations to reimagine itself. South African population black people or white people - should see the city centre as a mission field, not done by a remote control, but by incarnational presence in order to demonstrate the love and the person of Christ. Verster (2013) summarises it correctly that:

When the demographics of an area change and the church cannot adapt to the changed community it serves, its original congregation has moved or becomes unwilling to travel large distances to the existing building, or the area simply no longer has a residential function, the building becomes redundant and must be adapted. (p. 118)
The call is for interaction, interconnection, embrace, inclusion and occupation, instead of flight, redundancy or remote missional endeavours.

\section{Acknowledgements Competing interests}

The author declares that he has no financial or personal relationships which may have inappropriately influenced him in writing this article.

\section{References}

Akintunde, O., 1999, 'White racism, white supremacy, white privilege, and the socia construction of race: Moving from modernist to postmodernist multiculturalism', Multicultural Education 7(2), 1-8.

Aristide, J.B., 1993, Aristide: An autobiography, Jean-Bertrand Aristide with Christopher Wargny, Orbis Books, Maryknoll, NY.

Bakke, R. \& Hart, J., 1987, The Urban Christian: Effective Ministry in Today's Urban World, InterVarsity Press, Downers Grove, IL.

Banks, R., 1988, Paul's idea of community. Eerdmans Publishers, Grand Rapids, MI.

Baron, E., 2017, 'The role of church youth in the transformation agenda of South African cities', HTS Teologiese Studies/Theological Studies 73(3), a4771. https:// doi.org/10.4102/hts.v73i3.4771

Botman, R., 2000, 'Is blood thicker than justice? The legacy of Abraham Kuyper for Southern Africa (pp. 342-361), in L.E. Lugo (ed.), Religion, pluralism, and public life: Abraham Kuyper's legacy for the twenty-first Century, W.B Eerdmans Publishing, Grand Rapids, Ml.

Carter, S.L., 1993, The culture of disbelief, Anchor, New York

Chester, T. \& Timmis, S., 2008, Total church: A radical reshaping around gospel and community, Crossway Books, Wheaton, IL.

Clapp, R., 1996, A Peculiar people: The Church as culture in a post-Christian society, InterVarsity Press, Downers Grove, IL.

Coertzen, H., 2001, 'Kerkgebou se klanke stil sedert begin van sloping', Die Volksblad, Vrydag 16 Februarie 2001, viewed 10 September 2018, from http://152.111.11.6/ argief/berigte/volksblad/2001/02/16/9/1.htm

Davis, M., 2007, Planet of slums, Verso, London.

De Beer, S.F., 2017, 'Urban social movements in South Africa today: Its meaning for theological education and the church', HTS Teologiese Studies/Theological Studies 73(3), a4770. https://doi. org/10.4102/hts.v73i3.4770

De Villiers, J., 2012, 'Muslims by Joburg city Dutch Reformed Churches', in City Press, 16 April, viewed 10 September 2018, from $\mathrm{http}: / / 152.111 .1 .87 /$ argief/berigte/ citypress/2012/04/16/CP/5/church.html

Diangelo, R., 2018, White fragility: Why it's so hard for white people to talk about Racism, Beacon Press, Boston, MA.

Frazee, R., 2001, The connecting Church: Beyond small groups to authentic community Zondervan Publishing House, Grand Rapids, MI.

Geel, L. \& Beyers, J., 2018, 'The apparatus theory: "Religion in the city"', HTS Teologiese Studies/ Theological Studies 74(4), 4927. https://doi.org/10.4102/hts. v74i4.4927

Gibbs, E. \& Coffey, I., 2001, Church next: Quantum changes in Christian Ministry, InterVarsity Press, Leicester.

Göranzon, A., 2011, The prophetic Voice of the South African Council of Churches after 1990: Searching for a renewed Kairos, Swedish Institute of Mission Research, Uppsala, Published Thesis degree, viewed 10 September 2018, from http://urn. kb.se/resolve?urn=urn:nbn:se:uu:diva-151766

Hankela, E., 2013, 'Rules of reciprocity and survival in negotiating Ubuntu at the Central Methodist Mission in Johannesburg', Journal of Theology for Southern Africa 147, 74-90.

Harris, C.T., Noëth, J.G., Sarkady, N.G., Schutte, F.M. \& Van Tonder, J.M., 2010. Van Seringboom tot Kerkgebou: Die argitektoniese erfenis van die Gereformeerde Kerke, GKSA, Krugersdorp.

Ilo, S.C., 2017, 'Currents in World Christianity and the challenges of border-crossing and intercultural theology', Journal of Theology for Southern Africa 158, 37-56.

Johnson, S., 2018, 'Speaking together differently to live together differently: The promise of the public dialogue movement', Religious Education 113(3), 277-288. https://doi.org/10.1080/00344087.2018.1455568

Kerk en Samelewing (KS), 1986, 'n Getuienis van die Ned Geref Kerk, NG Sendingpers, Bloemfontein.

Kerk en Samelewing (KS), 1990, 'n Getuienis van die Ned Geref Kerk, NG Sendingpers, Bloemfontein.

Kgatla, S.T., 2016, 'Church and South African realities today: Towards a relevant missiology of radical discipleship', Stellenbosch Theological Journal 2(2), 57-75. https://doi.org/10.17570/stj.2016.v2n2.a03

Kiaziku, V.C., 2009, Culture and inculturation: A Bantu viewpoint, Pauline Publications Africa, Nairobi. 
Kritzinger, J. \& Mande, M., 2016, 'Theology disrupted by the challenge of refugee children', HTS Teologiese Studies/Theological Studies 72(1), a3546. https://doi. children, HTS Teologiese Stud
org/10.4102/hts.v72i1.3546

Lewis, R. \& Wilkins, R., 2001, The Church of irresistible influence, Zondervan Publishers, Grand Rapids, MI.

Magezi, V., 2017, "Glocal" and integrated churches within a practical theological imagination of "home away from home": Towards a ministry of migrants and refugees in diaspora', Stellenbosch Theological Journal 3(1), 227-250. https://doi. org/10.17570/stj.2017.v3n1.a11

Masuku, T.M., 2014, 'Prophetic mission of faith communities during apartheid South Africa, 1948-1994: An agenda for a prophetic mission praxis in the democratic SA' Missionalia 42(3), 151-167, viewed 10 September 2018, from http://missionalia. journals.ac.za

McClung, F., 2008, You see bones I see an Army, Struik Christian Books, Cape Town.

Palmer, T.P., 1994, African Christian theology: A new paradigm, viewed 11 September 2017, from http://www.tcnn.org/articles/RB56_Palmer.pdf

Parsley, R., 2007, Culturally incorrect: How clashing worldviews affect our future, Thomas Nelson Publishers, Nashville, TN.

Prozesky, M., 2016, 'Honest to God and the South African Churches in 2016', Acto Theologica 36(1), 152-169. https://doi.org/10.4314/actat.v36i 1.9 ISSN 23099089@UV/UFS

Rainer, T.S. \& Geiger, E., 2006, Simple Church, B\&H Publishing Group and LifeWay Research, Nashville, TN.

Ramphele, M., 2017, Dreams, Betrayal and Hope, Penguin Books, Cape Town.

Regel, M. \& Schulz, M., 1995, The Death of the Church, Zondervan Publishers, Grand Rapids, MI.

Renkin, W., 2017, 'Responses to migration: Tensions and ambiguities of churches in Pretoria Central and Mamelodi East', HTS Teologiese Studies/Theological Studies 73(3), a4725. https://doi.org/10.4102/hts.v73i3.4725

Resane, K.T., 2017, Communion Ecclesiology in a Racially Polarised South Africa, Sun Media, Bloemfontein.

Rhodes, S.A., 1998, Where the Nations Meet: The Church in the Multi-Cultural World, InterVarsity Press, Downers Grove, IL.

Ribbens, M. \& De Beer, S.F., 2017, 'Churches claiming a right to the city? Lived urbanisms in the City of Tshwane', HTS Teologiese Studies/Theological Studies 73(3), a4690. https://doi. org/10.4102/hts.v73i3.4690
Roger, R., 1997, Cities for a Small Planet, Faber \& Faber, London.

Rossouw, P.F., 2016, 'Inclusive communities: A missional approach to racial inclusivity within the Dutch Reformed Church'. Stellenbosch Theological Journal 2(1) 381-396. https://doi.org/10.17570/stj.2016.v2n1.a19

Selçuk, M., 2018, 'Learning in encounter: Crossroads, connections, collaborations', Religious Education 113(3), 233-243. https://doi.org/10.1080/00344087.2018.1450609

Sheldrake, P., 2010, Explorations in spirituality: History, theology and spiritual practice, Paulist Press, New York.

Soal, A.D. \& Henry, D., 2018, 'The reversal of Babel: Questioning the early church's understanding of the gift of the Holy Spirit in Acts as a reversal of the curse of Babel', Verbum et Ecclesia 39(1), a1842. https://doi. org/10.4102/ve.v39i1.1842

Stetzer, E. \& Rainer, T., 2010, Transformational Church, B\&H Publishing Group and LifeWay Research, Nashville, TN.

Strauss, P.J., 2018, 'Johan Heyns and critique in the Dutch Reformed Church against apartheid: The moderator a prophet?', HTS Teologiese Studies/Theological Studies 74(3), 4965. https://doi.org/10.4102/hts.v74i3.4965

Strauss, P.J., 2018, Wat het die Wêreldgemeenskap van Gereformeerde Kerke in 1998 en die Wêreldraad van Kerke in 2015 beweeg om die Ned Geref Kerk as lid terug te neem? Ongepubliseer.

Sundberg, W., 2000, 'Religious trends in Twentieth-Century America', Word \& World 20(1), 22-31. Luther Seminary, St. Paul, MN.

Tilly, M., 2016, 'Social equality and Christian Life in Paul's First Letter to the Corinthians', Acta Theologica Suppl 23, 225-237. https://doi.org/10.4314/actat.v23i1S.11

Toler, S. \& Nelson, A., 1999, The Five Star Church, Regal Books, Ventura.

Van der Westhuizen, C., 2016, 'Afrikaners in post-apartheid South Africa: Inward migration and enclave nationalism', HTS Teologiese Studies 72(1), a3351. https:// doi.org/10.4102/hts. v72i1.3351

Verster, W., 2013, A study of the life-cycle, re-use and adaptation of places of worship in Bloemfontein from 1948 to the present, with specific reference to the Afrikaan Reformed Churches, viewed 10 September 2018, from http://scholar.ufs.ac. za:8080/xmlui/handle/11660/2130

Volf, M., 1996, Exclusion and embrace: A theological exploration of identity, otherness, and reconciliation, Abingdon Press, Nashville, TN.

Wekker, G., 2016, White innocence: Paradoxes of Colonialism and Race, Duke University Press, Durham and London.

Zille, H., 2016, Not without fight: The autobiography, Penguin Books, Cape Town. 